\title{
Myths, models and human evolution
}

What on earth can safely be said in public about human evolution? The charitable among those who heard Dr J. R. Durant's Darwin lecture to the British Association this year will have been worrying at this question for the past three weeks. The title of Dr Durant's address - The Myth of Human Evolution tells the tale sufficiently: the stories that people tell, he argued, and which have been used for various purposes by people as different as Freud and Galton, Lorenz and E.O. Wilson, are but myths; "theories of human evolution have come to embody contemporary hopes and fears about the society in which we live". Specifically, the accusation goes, since the time of Raymond Dart until quite recently, the story told of human evolution has involved a model of human nature which is consistent with the doctrine of Adam and Eve, the Garden and the Fall, the doctrine of Original Sin, the notion that each contemporary human being is a battleground between civility (in the strict sense) and the primitive and powerful Beast within. The notion that primitive men were not merely successful hunters of other species but killers of each other, Durant says, fitted well with contemporary views of society at war within itself. But now, says Dr Durant, the fashion is changing. In making the public legend of human evolution, people have taken to describing primitive humans or hominids as creatures whose survival depended on cooperation between individuals and among groups, whose behaviour was shaped by an implicit recognition of the benefits of the division of labour in a hunter-gatherer society which Adam Smith first clearly described, and whose distinctive attribute - that of language - predisposes towards communality. What view, it might innocently be asked, is right? Neither, said Dr Durant. Each is a myth. Tell us instead, he asked of palaeoanthropologists, palaeoarchaeologists and the rest, the truth. Or at least acknowledge that your data are insufficient to say very much at all.

Stirring stuff like this is certain to evoke some kind of a response. Dr Durant will not have been surprised that, to begin with, the British daily newspapers were hesitant in knowing where he stood. Was he an anti-Darwinist, a Lamarckian or perhaps even a Creationist? When the fine print showed that he is none of these things, the tide of excitement ebbed. Mr Ronald Reagan, running for President of the United States, had in any case captured more attention with his aside in Dalias, Texas on the teaching of evolution in American schools (and may yet capture the Creationist vote in the United States with a sufficiently wellcalculated goof.)

Durant's complaint, in any case, was a complaint against a style of argument. His targets were writers such as Lorenz (in the old school) and E.O. Wilson (in the newer fashion). His audience, given its provenance, may not fully have appreciated that Durant had selected pushovers for his attack. "Criticize Lorenz's concept of innate aggression" must now be a standard essay topic in undergraduate biology courses in most universities. Before long it will be joined by topics such as "What is the evidence (if any) for the belief that genetically determined altruism has played a part in human evolution?"'. He was entirely within his rights to complain that, in much of what passes for a general account of the evolution of human beings and of human nature, people who should know better are too fond of making too much of far too little evidence. Their common error is to take a living primate species as a model for earlier - and even contemporary - human (or hominid) society. Human nature being what it is, it is not surprising that these reconstructions reflect their prejudices or their hopes of wish fulfillment.

So far, so good. Dr Durant must have been well satisfied with his attack on such a variety of false prophets. Yet there is more than this to say and to ask. Why, for example, does the question of human evolution evoke such powerful interest, and such passion? What is to be said with confidence in such a field, where the data are likely always to be insufficient? And how should an account of human evolution be constructed - and made immune to the attentions of the myth-makers?

Nobody should be surprised that these issues excite deep and general interest. Long before Darwin made it possible to talk about the issues in concrete terms, people at large were understandably preoccupied with the subject matter of Genesis. All writers on the human condition have.found it necessary to tackle the same questions - although it remains a puzzle that the Greeks, typified by Plato in the Laws, contemplated a past more or less indistinguishable from their present. For the past century, however, the public interest in human evolution has mostly been guided by Darwin's terms of reference. It would have been charitable of Dr Durant to have acknowledged that that is a step forward, and away from myth. But there is, as he complained, some way to go.

The lack of evidence is the chief stumbling block. The palaeoanthropologists may not really agree, but they are fortunate among those who work on human evolution. They have bones and other objects to measure, but past behaviour has left no fossils, only occasional artefacts from which behaviour must be inferred. In the circumstances, it is remarkable how much has been accomplished with the fossils uncovered in the past halfcentury. The time-span of human and earlier hominid evolution has been pinned down more accurately than could have been hoped a decade ago: 3.25 million years, give or take the usual ten per cent, will span the earliest australopithecine so far known ( $A$. afariensis) and the present. Anatomical evidence appears to make possible the distinction between potential ancestors of hominids and apes among the contemporaries of late-Tertiary Ramapithecus. The palaeoanthropologists have been helped along by pieces of unexpected good luck - such as the way in which genetic differences between extant primate species will increasingly be used as evolutionary clocks. Even so, the reconstruction of this relatively tangible part of human evolution is full of uncertainty. Was Homo habilis an ancestor, or a dead end? Which of the specific names which the palaeoanthropologists have put into circulation will survive discoveries not yet made? Calculated scepticism - which jibes uneasily both with the temperament of the practitioners and the expectations of the public - is clearly essential.

So how, with such caveats, can progress be made towards a robust understanding of how early people, and hominids, behave? Most of Dr Durant's complaints were levelled at those who have embellished fossils with patterns of behaviour for which there is no evidence. He may have unfairly overlooked the opportunities that do exist for tackling these questions empirically - for example, by constructing models of the coordinated evolution of anatomy and behaviour, using data gathered not merely from the fossil beds but from analyses of the structure of, say, intelligence, observations by psychologists of the acquisition of specified skills in infants and other primate species and even the evolutionary implications of, say, protein biochemistry.

The trouble, of course, is that models are easily misunderstood. The safeguard, in this field as in, for example, cosmology, is that their function should be widely understood. A model is but a hypothesis to be tested. To regard it otherwise is to make a myth of it. 